\title{
Extinction of a continuously rewarded barpressing response following continuous or partial reinforcement of a running response in rats
}

\author{
ROBERT L. WOODS and CHARLES I. BROOKS \\ King's College, Wilkes-Barre, Pennsylvania 18702
}

\begin{abstract}
Following either continuously reinforced (CR) or partially reinforced (PR) training in a runway, rats received $C R$ barpress acquisition and extinction. The PR runway-trained group showed significantly greater resistance to extinction of the barpressing response than did the CR runway-trained group.
\end{abstract}

Wenrich, Eckman, Moore, and Houston (1967) found increased resistance to extinction of continuously rewarded (CR) barpressing after partially rewarded (PR) runway training. Although their study supports the idea of transfer of persistence across different situations and response systems, the durability of this persistence is not clear from their procedure. That is, following runway training, only 75 rewarded barpresses were allowed prior to barpress extinction. The present study attempted to see if PR runway training would increase persistence of barpress responding during extinction following more extensive intervening CR barpress training. Additionally, unlike Wenrich et al. (1967) and a recent study by McCuller, Wong, and Amsel (1976) which showed the transfer effect from PR barpress training to runway extinction, the present study completely terminated the partial training in one situation before beginning acquisition and extinction in the second situation. It was felt that such a separation would provide a better test of the hypothesis that behavioral persistence transfers across different response systems and situations.

\section{METHOD}

\section{Subjects}

The subjects were 30 experimentally naive male albino rats, 90 days of age on delivery from the Holtzman Company, Madison, Wisconsin. The subjects were housed in individual cages and maintained on ad-lib food and water for 1 week before beginning the experiment.

\section{Apparatus}

The straight runway was $10.0 \times 9.0 \mathrm{~cm}$, with a sanded Plexiglas top. The runway was divided into three sections by guillotine doors: a $20.5-\mathrm{cm}$ startbox, a $129.5-\mathrm{cm}$ alley, and a

This research was completed as part of an independent research project in the Psychology Department at King's College by the senior author. Both authors thank Wallace and Dorothy McAllister for their comments on the manuscript. Requests for reprints should be sent to Charles I. Brooks, Department of Psychology, King's College, Wilkes-Barre, Pennsylvania 18702. $30.0-\mathrm{cm}$ goalbox. Running time was measured by a Lafayette timer in $.01 \mathrm{sec}$ from the interruption of a photobeam in the alley section, $15.5 \mathrm{~cm}$ from the startbox door, to the interruption of a second photobeam, $107.5 \mathrm{~cm}$ from the startbox door. Goal time was measured from the interruption of the second photobeam to the interruption of a third photobeam in the goalbox, $20.0 \mathrm{~cm}$ from the end of the runway. Rewards (45-mg Noyes food pellets) were placed in a round metal cup which was attached to the end wall of the runway, $4.5 \mathrm{~cm}$ above the floor.

The Skinner box was $22.5 \times 20.2 \times 19.0 \mathrm{~cm}$ high, with Plexiglas walls and top and a grid floor with stainless steel rods placed $1.5 \mathrm{~cm}$ apart. Rewards (45-mg Noyes pellets) were delivered in a foodcup $3 \mathrm{~cm}$ below and to the right of a protruding bar which was $4.5 \mathrm{~cm}$ above the floor.

\section{Design and Procedure}

The subjects were randomly assigned to either CR or PR runway acquisition. On Days 1-12, the subjects were handled daily and maintained on a deprivation schedule of $15 \mathrm{~g}$ of Wayne Lab Blox per day with free access to water. On Day 13, each subject was placed individually in the runway apparatus for a 5-min exploration period. On Days 14-23, each subject received five runway trials per day, for a total of 50 trials.

The CR subjects were reinforced on each trial. The PR subjects received a random $50 \%$ schedule of rewards and nonrewards, with the restriction that no more than three rewarded or nonrewarded trials occurred on a given day. Rewards consisted of a single 45-mg Noyes pellet and nonrewards of a 20-sec confinement in the empty goalbox.

On Day 24, each subject was given a 20-min exploration period in the Skinner box. On Day 25, barpress training began. Each subject received $20 \mathrm{~min}$ of CR training each day until it reached a criterion of 200 responses within a daily $20-\mathrm{min}$ period. Twenty-four hours after the subject reached the acquisition criterion, $20 \mathrm{~min}$ of extinction in the Skinner box was administered.

\section{RESULTS}

Runway acquisition times were converted to speeds by a reciprocal transformation. Analyses of variance (groups by trials) were performed on both the runway and goal speeds over Trials 41-50, and showed in each case main effects of trials only (Fs $=9.71$ and 5.13 , $\mathrm{dfs}=9 / 252$, ps $<.001$, for running and goal speed, 


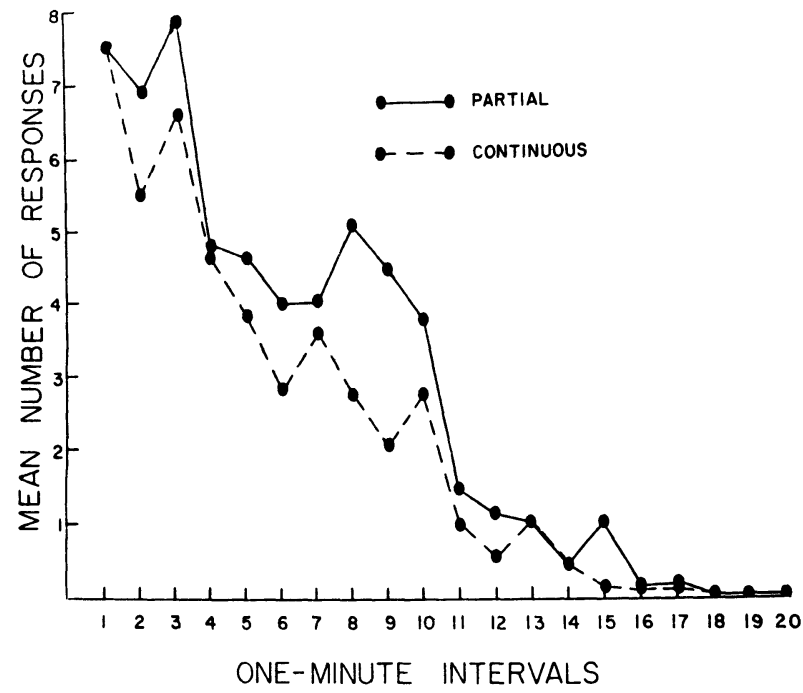

Figure 1. Mean number of barpressing responses during 1-min intervals of barpress extinction following either continuously or partially reinforced runway acquisition.

respectively.) Neither measure showed a groups main effect or a Groups by Trials interaction (all ps $>.20$ ).

All subjects reached the barpressing criterion within three 20-min sessions. A t test comparing the mean total number of responses during barpress training for the $\mathrm{CR}$ runway subjects (mean $=414.2$ ) with that for the PR runway subjects (mean $=420.6$ ) was found to be nonsignificant $(\mathrm{p}>.20)$.

Figure 1 presents the mean number of barpressing responses over 1-min intervals during extinction for the two runway-reward schedule groups. Whereas both groups showed a steady decline in barpressing frequency, the partially trained subjects were consistently superior to the continuously trained subjects over the first 12 min of barpress extinction. A groups by minutes analysis of variance on the data in Figure 1 confirmed this apparent superiority of the partial subjects $(F=$ $5.98, \mathrm{df}=1 / 28, \mathrm{p}<.001)$. The analysis also provided a significant effect of minutes $(F=32.11$, df $=19 / 532$, $\mathrm{p}<.001)$ but no interaction of Groups by Minutes $(\mathrm{F}<1)$.

\section{DISCUSSION}

The present results support those of Wenrich et al. (1967), in that partially rewarded runway training increased persistence of responding during barpress extinction. Furthermore, the data indicate that the transfer effect endured through several barpress training sessions, and occurred even though there was no overlap of training in the two situations. Combined with the recent data reported by McCuller et al. (1976), the present results and those of Wenrich et al. (1967) support the conclusion that transfer of persistence can occur across different instrumental response systems.

\section{REFERENCES}

McCuller, T., Wong, P. T. P., \& Amsel, A. Transfer of persistence from fixed-ratio barpress training to runway extinction. Animal Learning \& Behavior, 1976, 4, 53-57.

Wenrich, W. W., Eckman, G. E., Moore, M. J., \& Houston, D. F. A trans-response effect of partial reinforcement. Psychonomic Science, 1967, 9, 247-248.

(Received for publication June 22, 1977.) 